\title{
Exploring the Personal, Social and Occupational Elements of Teacher Professional Development
}

\author{
Vivien McComb ${ }^{1}$, Narelle Eather ${ }^{1}$ \\ ${ }^{1}$ Senior Academic Developer, The University of Newcastle, Australia \\ Correspondence: Vivien McComb, Senior Academic Developer, The University of Newcastle, Australia.
}

Received: October 15, 2017

doi:10.11114/jets.v5i12.2794
Accepted: November 12, $2017 \quad$ Online Published: November 13, 2017

URL: https://doi.org/10.11114/jets.v5i12.2794

\begin{abstract}
In a neoliberal political context, educational reform is seen as largely dependent on the individual teacher and his or her ability to continue developing and improving his or her practice with the ultimate goal of improving student outcomes. Professional development (PD) is therefore reliant on teachers to embrace new models of practice, to engage with these new approaches, to correctly interpret the PD ideas for application to the teaching and learning process, and ultimately implement new models and ideas in their classrooms (Huber \& Hiltmann, 2011). This paper seeks to examine more closely three aspects of PD that have been found in the research literature to have a significant impact on the effectiveness of PD programs, because of their focus on, and consideration of the individual teacher. Aligning with Fraser, Kennedy, Reid, and McKinney (2007), successful PD programs that have a distinct focus on the personal, social and occupational aspects of teacher development will be discussed.
\end{abstract}

Keywords: teacher professional development, teacher beliefs, communities of practice, transformative learning, critical reflection

\section{Introduction}

A neoliberal political agenda has led to increased pressure on schools and teachers to be directly accountable for improving teaching practice and for attaining standardised student outcomes (educational reform) as a result of government regulation (Bloomfield, 2008). Professional Development (PD) programs for teachers are one of the main vehicles used to achieve educational reform and to meet government standards (Mockler, 2013). Effective PD programs are generally sustainable, future-focused, relevant, collaborative and provide opportunity for teachers to reflect on their beliefs about practice (AITSL, 2012c; Barrera-Pedemonte, 2013; Getenet, Trimble, \& Nailon, 2013; Huber \& Hiltmann, 2011; OECD, 2009). This paper will focus on the individual teacher in three key target areas of the PD context: personal (confront and reflect on their beliefs), social (importance of teacher collaboration) and occupational (teacher learning focused on pedagogy and student learning) (Fraser, Kennedy, Reid, \& Mckinney, 2007).

\subsection{Neoliberalism - Teacher Education Reform Context}

Neoliberalism impacts on education and posits an 'education as business model' (Fraser et al., 2007), where we see more government regulated and imposed teacher PD, where teachers are seen as a 'corporate entity', students and parents are viewed as 'clients'; and teaching practice is increasingly standardized and viewed as the responsibility of the individual teacher (Bloomfield, 2008; Fraser et al., 2007; Mockler, 2013). That is, individual teachers are held responsible for maintaining and documenting their professional practice in line with an external regulator and must abide by specific auditing and reporting processes to remain accredited and employable in the teaching profession (Bloomfield, 2008). Consequently, neoliberalsim has a significant impact on how teachers are viewed, the role and purpose of PD and the broader educational reform agenda. That is, the focus is on improving teacher quality and individual teaching practices as the main vehicle to achieve overall educational reform (including raising the educational outcomes of all students) (Bloomfield, 2008; Fraser et al., 2007; Mockler, 2013).

Neoliberalim is seen in education, for example, in the heavily-regulated NSW, Australia, Board of Studies Teaching and Educational Standards that requires individual teachers to seek accreditation first and then ongoing levels of attainment beyond their initial tertiary teaching qualifications (See NSW BOSTES Teacher Accrediation-http://www.nswteachers.nsw.edu.au/). Under this accreditation model, teachers are expected to achieve given standards, at four levels across their teaching career, graduate, proficient, highly accomplished, and lead. The 
Department for Education in England, also has Teachers' Standards, used to frame teacher development and levels of attainment: trainees completing their statutory induction period; newly qualified teachers (NQTs) working towards quality teacher status (QTS), and to assess the performance of teachers in "maintained schools... who are covered by the 2012 appraisal regulations" and who hold qualified teacher learning and skills (QTLS, p.3) status (See https://www.gov.uk/government/uploads/system/uploads/attachment_data/file/301107/Teachers_Standards.pdf).

Similarly, the U.S Department of Education has implemented a number of core reforms aimed at promoting 'excellent teaching' and improved student outcomes. These reform processes are administered by the National Board for Professional Teaching and Standards, and include teacher training and preparation, teacher certification (http://www.boardcertifiedteachers.org/) and the U.S. Department Teach to Lead program (See http://www.nbpts.org/). To become a board-certified candidate, teachers must hold a Bachelor's Degree, have three years of teaching experience and hold a state teaching license. The comprehensive certification process requires teachers to complete a portfolio of work including four specific teaching components related to their teaching subject area and level.

\subsection{Professional Development}

Given the current state of education and the resulting emphasis being placed on teacher PD as the main vehicle to achieve improved educational outcomes, it is important that the PD programs and processes being offered to teachers through government regulated processes be of a high standard and have the desired impact on teaching practices and student outcomes. Achieving this is complex and fraught with difficulty given the many stakeholders (teachers, students, parents, community, government and regulators) and elements involved in the process of effective PD. There is strong consensus in the research literature that for PD to be effective it needs to be future focused, sustained, relevant (to individual teaching practice, subject matter and pedagogy) and collaborative in nature; and it needs to provide opportunity for teachers to critically reflect on their beliefs about practice and have opportunity to consciously improve their current practice (AITSL, 2012c; Barrera-Pedemonte, 2013; Getenet et al., 2013; Huber \& Hiltmann, 2011; OECD, 2009).

This paper seeks to examine more closely three key aspects of PD evident in the research literature that have been shown to have a significant impact on the effectiveness of PD programs because of their focus on the consideration of the individual teacher. Aligning with Fraser and others (2007), successful PD programs that have a distinct focus on the:

1) Personal - giving teachers an opportunity to confront their deeply held beliefs and reflect on their practice; 2) Social - the importance of teacher collaboration in the PD context; and 3) Occupational - teacher learning in relation to practice (deepening understanding of student learning in relation to subject matter and pedagogy) aspects of teacher development are discussed. The ultimate goal of this paper is to deepen our understanding of these three key aspects of PD programs and their significance to individual teacher learning.

\section{Personal - Providing Teachers with the Opportunity to Confront and Reflect on Their Beliefs}

Teacher beliefs within the context of PD programs have been broadly researched. For example, previous investigations have sought to evaluate teacher beliefs in relation to epistemology, experiences within given contexts, subject areas, self-efficacy, students and the learning process, teacher perspectives on PD programs, and facilitating teacher learning, to name a few (Cole, 2012; Goos, Dole, \& Makar, 2007; Pedersen \& Liu, 2003; Richardson, 1996; Thomas \& Pedersen, 2003). There is strong consensus in the academic literature that teacher beliefs influence teaching practice (Pajares, 1992; Pedersen \& Liu, 2003; Rimm-Kaufman \& Sawyer, 2004; Vartuli, 2005; Wilson, Readence, \& Konopak, 2002) and that teacher beliefs are one of the key constructs to be understood in relation to informing and improving teaching practices (Isenberg, 1990; Pajares, 1992; Pedersen \& Liu, 2003; Vartuli, 2005). For example, research shows that teachers hold strong beliefs about every element of the teaching process, including: beliefs about their subject area; beliefs about the preparation students need to meet specified standards; and beliefs about appropriate instructional or pedagogical methods needed in given contexts and for students of varying backgrounds and abilities (Anderson \& Helms, 2001). Therefore, in order for PD to be effective and transformative in nature, with improvement and development of teaching practice, teachers will need to be provided with opportunities to confront their beliefs about the teaching and learning process (Huber \& Hiltman, 2011), and engage in critical reflection processes (Brookfield, 2002; Cranton \& King, 2003). Huber and Hiltmann (2011) suggest that "PD has to take over a diagnostic function much more explicitly. By integrating elements of self-assessment and feedback, the prior knowledge, subjective theories, attitudes, expectations, goals, and the motivation of the potential participants can become the starting point for the conception of continuing professional development, to which the learning approaches have to be linked" (p. 69).

Loucks-Horsley and Matsumoto (1999) suggest that when confronting their deeply held beliefs about the teaching and learning process, some conflict or dissonance needs to be engendered between held beliefs and new ideas, so that the assumptions teachers hold about themselves and students within the teaching and learning process that inhibit learning, can be dispelled and new beliefs formed. To do this, it is recommended that PD programs provide opportunities for 
teachers to critically reflect upon, question and analyse their held beliefs and values in relation to teaching and learning processes. As a result, teachers can then begin to adopt new schema around improved teaching practice (leading to improved student learning outcomes) as they are presented with new ideas and recommended reform measures (Timperley \& Robinson, 2001). In this process of critical reflection on the PD process, teachers will develop an understanding of what may happen when belief systems are challenged and changed, and will have the opportunity of adopting and applying new belief systems within their teaching practice, leading to transformative learning (Brookfield, 2002; Cranton \& King, 2003; Mezirow, 1990).

Teacher learning within the PD context requires change to occur in the affective (e.g., teacher beliefs and attitudes) and pedagogical domains, and in the habits the teachers have formed in the teaching and learning process (Fisler \& Firestone, 2006). Fisler and Firestone (2006) completed an extensive three-year longitudinal study evaluating the effectiveness of a university-school based pedagogical PD intervention for teachers. Interviews, observations, document analysis and surveys were conducted, and changes to teaching practices were assessed. Teachers were categorized according to the level of change to beliefs and practice, from: 1) 'restructurers' who exhibited extensive pedagogical and affective learning and held high self-efficacy beliefs, to 2) 'reviewers' who made small, superficial changes to their practice and self-efficacy beliefs, and 3) 'resisters' who failed to make positive changes to their practice and their self-efficacy beliefs throughout the three-year study. The results of the study indicated that the beliefs teachers hold about their ability to have a positive influence on their students' learning greatly impacts on the teachers' willingness to persevere in the face of obstacles, and in the teacher's ability to make the necessary changes to improve teaching practice - ultimately impacting on student achievement (Fisler \& Firestone, 2006). Fisler and Firestone suggest that higher levels of teacher efficacy, or belief in one's ability to perform, may be an important element in determining teacher effectiveness for achieving student outcomes.

The literature suggests that PD programs seeking to change teacher beliefs and ultimately improve teaching practice, need to provide opportunity for teachers to critically reflect on their held beliefs, and couple this with the provision of leadership support as teachers make changes to their practices (Dwyer, Ringstaff, \& Sandholtz, 1991; Richardson, 1996; Timperley \& Robinson, 2001). This was found to be evident in research by Timperley and Robinson (2001), where they completed a study based on schema theory in four schools, and examined changes in teacher beliefs about the causes of low student academic achievement levels. This study was completed over a two-and-a-half year period. Collection methods for the study included observations, interviews and questionnaires. Teachers in all four schools held schema that attributed poor student achievement levels to external sources, such as lack of parental involvement and low skill levels of students. When teachers were shown discrepant data to their existing beliefs, teachers were given the opportunity to reflect on and question their held beliefs and developed a different understanding in relation to their role in the achievement levels of students. Teachers in three of the four schools within the study demonstrated changes to their previously held thinking and teaching practices. Researchers were able to challenge the deeply held schemas of teachers and provide evidence to teachers that teaching practices were influential in improving student literacy levels. Timperley and Robinson (2001) state that "when particular assumptions supporting a larger schema are demonstrated to be faulty on several occasions, the framework of the schema itself comes under revision" (p. 290). Other conditions that were found to be necessary for changing teachers' beliefs and practice included having an external person to assist with data collection and interpretation, and the provision of examples of alternative practice to teachers. This transformation in some of the teachers' beliefs occurred because teachers were given opportunities to critically reflect on their assumptions, which is essential for transformative learning to occur (Cranton \& King, 2003; Mezirow, 1990). Cranton and King (2003) state that transformative learning has occurred when "educators are led to examine their practice critically and thereby acquire alternative ways of understanding what they do" (p. 32).

\section{Social - The Importance of Facilitating Teacher Collaboration in the PD Context}

Incorporating teacher collaboration in PD programs has been widely acknowledged as one of the main ways of implementing successful educational reform (Merriman Bausmith \& Barry, 2011). In the PD context, the process of challenging deeply held beliefs can be quite confronting for teachers. Therefore, it is important that there is effective collaboration between teachers built in to the PD program (Abadiano \& Turner, 2004; Blumenfeld, Fishman, Kracjik, \& Marx, 2000; Garet, Porter, Desimone, Birman, \& Yoon, 2001; Hargreaves, 1997; Loucks-Horsley \& Matsumoto, 1999) as teacher collaboration is thought to support and enhance teacher self-efficacy and aid in preventing burnout through the social and emotional support the collaboration engenders (OECD, 2009). This can be implemented within the subject discipline, or through wider collaboration between teachers within the school environment and outside the school in the broader educational community. This is important as teachers will be supported by this collaborative culture, as they take risks, reflect on their beliefs about the teaching and learning process, work together to solve problems, and as they begin to implement new teaching methods into their practice (Abadiano \& Turner, 2004; Getenet et al., 2013; Hargreaves, 1997; King \& Newmann, 2001; OECD, 2009). 
If PD is to effectively facilitate teacher learning, it needs to be encouraged through social connection and collaboration between teachers in schools. Fraser and others (2007) define the characteristics of effective teacher communities of practice as including teachers working together to develop teaching practice and resources, through sharing ideas and expanding their repertoire of teaching strategies and methods. A second example of teacher collaboration that seeks to enhance critical and reflective practice is the 'critical friend partnership' (Baskerville \& Goldblatt, 2009). This 'critical friend partnership' provides a formalized opportunity for teachers to work in partnership with a peer mentor to critically reflect on their practice and provide insight to one another in the development of their teaching practice (Baskerville \& Goldblatt, 2009). It is designed to provide robust peer review, constructive and critical observation and feedback on teaching practice, and teacher collaboration on all aspects of teaching practice.

According to the Orgnisation for Economic Cooperation and Development (OECD) (2009), teacher collaboration can take two forms, one being 'teacher exchange' (exchanging teaching materials and resources, discussion about the learning and development of individual students, jointly attending conferences and professional development programs and discussing the achievement of common policies and regulations) and the other being teacher 'professional collaboration' (teacher peer review of work including classroom observations and feedback, working together to implement the PD program into curriculum, pedagogy and subject areas across classes). It was found by the OECD (2009) that those teachers who engaged in one type of collaborative activity were more likely to be then involved in other types of collaborative activities compared to those teachers who did not collaborate with their teaching colleagues - supporting that collaborative activities build on and enhance further teacher collaborative relationships.

Penuel, Fishman, Yamaguchi, and Gallagher (2007) found in a study of 454 science teachers, that teachers reported a change to their teaching practice when they were engaged in PD with their colleagues. Penuel and others suggest that PD programs making use of teacher collaboration will be more successfully implemented for a number of reasons, including: collegial relationships focused on the same goals and purposes of a PD program can mean teachers work together on solving problems, enhancing motivation and perseverance in seeking improvement in student outcomes; teacher collaboration may also build trust, provide social capital and give value to the PD program when peers are supportive of the reform measures and are finding success in its application to practice; and there is also potential for the extension of teacher learning when more experienced peers provide additional support in the implementation of the reform measures (Penuel et al., 2007).

Vescio, Ross, and Adams (2008) conducted a literature review of ten empirical published studies and one multi-site research report in relation to the use of professional learning communities within schools and the impact these had on both teaching practice and student learning outcomes. The professional learning communities in the studies all displayed five essential characteristics needed for effectiveness - shared values and norms for student learning abilities, school use of time and space, and roles of all stakeholders (parents, teachers and administrators); clear and consistent focus on student learning (not on teaching students but ensuring that they learn); reflective teacher dialogue - extensive conversations between teachers about curriculum, pedagogy and student development; teaching made public; and focusing on teacher collaboration. Their findings showed that teachers participating in professional learning communities (with the five essential characteristics) became more student-centred in their teaching practice, the teaching culture was improved as a result of a focus in these communities on student learning and teacher continuous learning, and that there was an overall improvement in student achievement outcomes over time in all the schools involved (Vescio et al., 2008).

\section{Occupational - Teacher Learning in Relation to Practice}

It is essential that the content for PD programs have teacher learning as its focus and aims that seek to facilitate the learning cycle for participants (Vandenberghe, 2002). It is recommended that teacher learning in PD programs needs to focus on: the subject matter of the particular discipline and related curriculum; understanding the learner in the classroom, and the learning process in relation to the subject area; and improving and developing teaching methods or pedagogy used by the teacher within the classroom (Fishman, Marx, Best, \& Tal, 2003; Garet et al., 2001; Loucks-Horsley \& Matsumoto, 1999). Muir and Beswick (2007) conducted a review of the PD literature of mathematics teachers and found that effective PD focused on providing opportunities for teachers to learn more about content and pedagogy in relation to their classroom practice. The literature also highlights that teachers need to learn about themselves as teachers (through self-reflection), the learners in the classroom and the teaching and learning process in itself (Vandenberghe, 2002).

Getenet et al. (2013) emphasise the importance of PD programs being relevant to teachers and their need to improve student learning, engagement and outcomes. For example, PD programs that focus on training teachers in understanding how students learn their particular subject area have proven successful in improving student achievement (Loucks-Horsley \& Matsumoto, 1999). That is, Ancess (2000) found that when teachers were given opportunities to 
develop learning goals for their students in relation to their own practice, they began to analyse and reflect on their own practices, leading to practices that were more effective in achieving student outcomes. Therefore, having PD programs for teachers that have a focus on the learning and development of students influences the attitudes, beliefs and knowledge of teachers, and ultimately results in teacher learning.

Griffiths, Gore, and Ladwig (2006) completed initial research within the longitudinal Systemic Implications of Pedagogy and Achievement in NSW Public Schools (SIPA) study, drawing from teacher interviews, questionnaires, classroom observations and student assessment tasks collected during this study. The study found that high quality teaching practice, as determined by the quality teaching (QT) framework, was influenced by the depth of understanding that teachers had of the QT framework in relation to teaching practice. High quality teaching practice was also influenced by higher levels of responsibility for students' learning and the teachers' self-efficacy beliefs, in terms of personal capacity to make a difference in the lives of their students. On the other hand, quality of teaching was not significantly influenced by years of teaching experience or other demographic characteristics, such as the socioeconomic status of the school. It was concluded from this study that pedagogical reform is unlikely to occur without teacher understanding of the pedagogy framework and affective components, such as, the teachers' commitment to their students' learning and self-efficacy beliefs about their own capacity to effect positive change in their students (Griffiths et al., 2006).

\section{Conclusion}

This paper provides an overview of some of the personal, social and occupational elements found to be important in providing effective PD to teachers that ultimately impacts on the improvement of teaching practices and student achievement outcomes. The literature supports that PD programs need to be action-oriented, giving individual teachers opportunity to critically reflect on and self-assess their practice, and exchange and share this learning with colleagues in a professional learning community within the school and the wider educational context. Some of the suggested ways of achieving this in practice include incorporating the following elements into teacher PD programs: teacher critical reflection, self-assessment and evaluation; time and opportunity for the integration of new ideas and models into practice; 'critical friend partnerships' that include collaboration through classroom observations, and shadowing and peer mentoring processes; professional learning communities within schools and through teacher communities and networks outside of the school; and the development of a teaching portfolio of work that includes planning and the documentation of learning progress and development, teacher reflections and evaluations.

\section{References}

Abadiano, H. R., \& Turner, J. (2004). Professional staff development: What works? The NERA Journal, 40(2), 87-91.

AITSL. (2012c). Australian charter for the professional learning of teachers and school leaders: A shared responsibility and commitment. Melbourne Victoria.

Anderson, R. D., \& Helms, J. V. (2001). The ideal of standards and the reality of schools: Needed research. Journal of Research in Science Teaching, 38(1), 3-16. https://doi.org/10.1002/1098-2736(200101)38:1<3::AID-TEA2>3.0.CO;2-V

Barrera-Pedemonte, F. (2013). High-Quality teacher professional development and classroom teaching practices: Evidence from talis 2013. Paris: OECD Publishing.

Baskerville, D., \& Goldblatt, H. (2009). Learning to be a critical friend: From professional indifference through challenge to unguarded conversations. Cambridge Journal of Education, 39(2), 205-221. https://doi.org/10.1080/03057640902902260

Bloomfield, D. (2008). Neo-liberal accreditation agendas: Challenges and opportunities for professional experience. Paper presented at the Australian Association for Research in Education, Brisbane.

Blumenfeld, P., Fishman, B. J., Kracjik, J., \& Marx, R. W. (2000). Creating usable innovations in systemic reform: Scaling up technology-embedded project-based science in urban schools. Educational Psychologist, 35(3), 149-164. https://doi.org/10.1207/S15326985EP3503_2

Brookfield, S. D. (2002). Using the lenses of critically reflective teaching in the community college classroom. New Directions for Community Colleges, 2002(118), 31-38. https://doi.org/10.1002/cc.61

Cole, P. (2012). Linking effective professional learning with effective teaching practice. Melbourne Australia: Institute for Teaching and School Leadership.

Cranton, P., \& King, K. P. (2003). Transformative learning as a professional development goal. New Directions for Adult \& Continuing Education, 2003(98), 31-38. https://doi.org/10.1002/ace.97 
Dwyer, D. C., Ringstaff, C., \& Sandholtz, J. H. (1991). Changes in teachers' beliefs and practices in technology-rich classrooms. Educational Leadership, 45-52.

Fishman, B. J., Marx, R. W., Best, S., \& Tal, R. T. (2003). Linking teacher and student learning to improve professional development in systemic reform. Teaching and Teacher Education, 19(6), 643-658.

https://doi.org/10.1016/S0742-051X(03)00059-3

Fisler, J. L., \& Firestone, W. A. (2006). Teacher learning in a school-university partnership: Exploring the role of social trust and teaching efficacy beliefs. Teachers College Record, 108(6), 1155-1185. https://doi.org/10.1111/j.1467-9620.2006.00689.x

Fraser, C., Kennedy, A., Reid, L., \& Mckinney, S. (2007). Teachers' continuing professional development: Contested concepts, understanding and models. Journal of In-Service Education, 33(2), 153-169. https://doi.org/10.1080/13674580701292913

Garet, M. S., Porter, A. C., Desimone, L., Birman, B. F., \& Yoon, K. S. (2001). What makes professional development effective? Results from a national sample of teachers. American Educational Research Journal, 38(4), 915-945. https://doi.org/10.3102/00028312038004915

Getenet, S., Trimble, A., \& Nailon, D. (2013). Perspectives on professional development in Australian education: Some realities of standards-based professional development. International Journal of Innovative Interdisciplinary Research, 2(12), 34-48.

Goos, M., Dole, S., \& Makar, K. (2007). Designing professional development to support teachers' learning in complex environments. Mathematics Teacher Education and Development, 8(Special Issue), 23-47.

Griffiths, T., Gore, J. M., \& Ladwig, J. G. (2006). Conceptions of pedagogy: Teacher understanding as a critical factor in professional learning and pedagogical practice. Paper presented at the Annual Meeting of the American Educational Research Association, San Francisco.

Hargreaves, A. (1997). Rethinking educational change. In A. Hargreaves (Ed.), Rethinking Educational Change with Heart and Mind. The 1997 ASCD Yearbook. Alexandria, VA: Association for Supervision and Curriculum Development.

Huber, S. G., \& Hiltmann, M. (2011). Competence profile school management (CPSM) - An inventory for the self-assessment of school leadership. Educational Assessment, Evaluation and Accountability, 23(1), 65-88. https://doi.org/10.1007/s11092-010-9111-1

Isenberg, J. P. (1990). Teachers' thinking and beliefs and classroom practice. Childhood Education, 66(5), 322-327. https://doi.org/10.1080/00094056.1990.10522549

King, M. B., \& Newmann, F. M. (2001). Building school capacity through professional development: Conceptual and empirical considerations. The International Journal of Educational Management, 15(2), 86-94. https://doi.org/10.1108/09513540110383818

Loucks-Horsley, S., \& Matsumoto, C. (1999). Research on professional development for teachers of mathematics and science: The state of the scene. School Science and Mathematics, 99(5), 258-270. https://doi.org/10.1111/j.1949-8594.1999.tb17484.x

Merriman, B. J., \& Barry, C. (2011). Revisiting professional learning communities to increase college readiness: The importance of pedagogical content knowledge. Educational Researcher, 40(4), 175-178. https://doi.org/10.3102/0013189X11409927

Mezirow, J. (1990). How critical reflection triggers transformative learning Fostering critical reflections in adulthood: A guide to transformative and emancipatory learning. New York, United States: John Wiley \& Sons.

Mockler, N. (2013). Teacher professional learning in a neoliberal age: Audit, professionalism and identity. Australian Journal of Teacher Education, 38(10), 34-47. https://doi.org/10.14221/ajte.2013v38n10.8

OECD. (2009). Creating effective teaching and learning environments: First results from TALIS. Paris: OECD. https://doi.org/10.1787/9789264068780-en

Pajares, M. F. (1992). Teachers' beliefs and educational research: Cleaning up a messy construct. Review of Educational Research, 62(3), 307-332. https://doi.org/10.3102/00346543062003307

Pedersen, S., \& Liu, M. (2003). Teachers' beliefs about the issues in the implementation of a student-centred learning environment. Educational Technology, Research and Development Washington, 51(2), 57-76.

https://doi.org/10.1007/BF02504526 
Penuel, W. R., Fishman, B. J., Yamaguchi, R., \& Gallagher, L. P. (2007). What makes professional development effective? Strategies that foster curriculum implementation. American Educational Research Journal, 44(4), 921-958. https://doi.org/10.3102/0002831207308221

Richardson, V. (1996). The role of attitudes and beliefs in learning to teach. In J. P. Sikula (Ed.), Handbook of Research on Teacher Education (2nd ed., pp. 102-119). New york: Simon \& Schuster Macmillan.

Rimm-Kaufman, S. E., \& Sawyer, B. E. (2004). Primary-Grade teachers' self-efficacy beliefs, attitudes toward teaching, and discipline and teaching practice priorities in relation to the responsive classroom approach. The Elementary School Journal Chicago, 104(4), 321-341. https://doi.org/10.1086/499756

Thomas, J. A., \& Pedersen, J. E. (2003). Reforming elementary science teacher preparation: What about extant teaching beliefs? School Science and Mathematics Bowling Green, 103(7), 319-330. https://doi.org/10.1111/j.1949-8594.2003.tb18209.x

Timperley, H. S., \& Robinson, V. M. J. (2001). Achieving school improvement through challenging and changing teachers' schema. Journal of Educational Change, 2, 281-300. https://doi.org/10.1023/A:1014646624263

Vandenberghe, R. (2002). Teachers' professional development as the core of school improvement. International Journal of Educational Research, 37(8), 653-659. https://doi.org/10.1016/S0883-0355(03)00063-6

Vartuli, S. (2005). Beliefs: The heart of teaching. Young Children, 60(5), 76-78, 80-86.

Vescio, V., Ross, D., \& Adams, A. (2008). A review of research on the impact of professional learning communities on teaching practice and student learning. Teaching and Teacher Education, 24, 80-91. https://doi.org/10.1016/j.tate.2007.01.004

Wilson, E. K., Readence, J. E., \& Konopak, B. C. (2002). Preservice and inservice secondary social studies teachers' beliefs and instructional decisions about learning with text. Journal of Social Studies Research Manhattan, 26(1), $12-23$.

\section{Copyrights}

Copyright for this article is retained by the author(s), with first publication rights granted to the journal.

This is an open-access article distributed under the terms and conditions of the Creative Commons Attribution license which permits unrestricted use, distribution, and reproduction in any medium, provided the original work is properly cited. 